Article

\title{
Apple Scion and Rootstock Contribute to Nutrient Uptake and Partitioning under Different Belowground Environments
}

\author{
Nadia A. Valverdi ${ }^{1, * \mathbb{D}}$, Lailiang Cheng ${ }^{2}$ and Lee Kalcsits ${ }^{1}$ (D) \\ 1 Department of Horticulture, Tree Fruit Research and Extension Center, Washington State University, \\ 1100 North Western Avenue, Wenatchee, WA 98801, USA \\ 2 Section of Horticulture, School of Integrative Plant Science, Cornell University, 236 Tower Road, Ithaca, \\ NY 14853, USA \\ * Correspondence: nadia.valverdi@wsu.edu
}

Received: 30 June 2019; Accepted: 27 July 2019; Published: 30 July 2019

\begin{abstract}
Soil environment strongly contributes to tree growth and development, affecting nutrient and water uptake. Composite woody perennials, like apple, are a combination of two genetically different parts: a rootstock and a scion, and yet, the role of each part on nutrient uptake and distribution under differing soil environments has not been previously studied. We tested how water limitations and elevated soil temperatures, applied to different apple rootstocks and scions, affected mineral nutrient uptake and distribution on young apple trees. Two one-year-old potted apple cultivars were grown in a greenhouse, 'Honeycrisp' and 'Gala,' combined with four rootstocks: G890, G41, M9, and B9. Belowground abiotic environmental treatments were imposed for 60 days after trees reached approximately $45 \mathrm{~cm}$ height. Water limitations reduced aboveground biomass and, to a lesser extent, root biomass. 'Gala' and the rootstock G890 showed elevated mineral nutrient uptake compared to 'Honeycrisp' and the other rootstock genotypes. Additionally, G890 showed greater plasticity for both biomass and mineral nutrient accumulation. Elevated soil temperatures increased the ratios of $\mathrm{K}: \mathrm{Ca}, \mathrm{N}: \mathrm{Ca}, \mathrm{Mg}: \mathrm{Ca}$, and $(\mathrm{N}+\mathrm{K}+\mathrm{Mg}): \mathrm{Ca}$ in leaf tissue of rootstock $\mathrm{G} 41$ and 'Honeycrisp'. These findings highlight the importance of the use of scion and rootstock genotypes that are adapted to specific soil environments to ensure optimal nutrient uptake.
\end{abstract}

Keywords: Malus domestica; water stress; root-zone temperature; biomass partitioning; nutrient balance

\section{Introduction}

Water availability is one of the most significant limitations to plant productivity and largely dictates the distribution of plant species around the world [1,2]. Many tree fruit producing arid regions are typically exposed to elevated abiotic stress including high light intensity, temperature, and low rainfall that can affect crop yield and quality [3]. Most of these regions frequently rely on irrigation to provide an adequate water supply to maintain orchard productivity [4] and fruit quality [5]. These irrigation-dependent regions may experience higher risks from variations in water availability and elevated temperatures in the future [6,7]. Although water and plant nutrition are inextricably linked, there is little information on how plant water status affects plant nutrient uptake and distribution, particularly for perennial tree species like apple.

Like many other fruit trees, apple (Malus $\times$ domestica Borkh.) trees are a combination of two genetically different parts: a rootstock and a scion. The rootstock constitutes the root system and a small portion of the lower trunk, and the scion forms the aboveground portion of the tree [8]. Rootstocks are essential components in productive apple orchards because of their contributions to water and nutrient 
uptake, anchorage, vigor control, precocity, pest and disease protection, and abiotic stress resistance [9]. The root systems in fruit trees are critical for nutrient and water uptake from the soil environment. These highly plastic systems have the capacity to scavenge heterogeneous soil environments to reach water and nutrient-rich regions $[10,11]$. Rootstocks have been shown a large degree of genotypic variation in architectural characteristics and phenotypic malleability that may affect how they respond to water supply [12].

Soil abiotic environment plays a vital role in aboveground scion tree growth and development. Changes in soil temperature have been shown to interact with other essential resources, including both water and nutrient availability [13]. Elevated soil temperatures, above $25^{\circ} \mathrm{C}$, can influence root growth, root turnover, and leads to increases in carbon losses due to higher rates of root respiration $[14,15]$. Changes in root growth and development and the availability of water and mineral nutrients in the soil matrix, are important factors that may contribute to differential responses of apple rootstocks to the soil environment. These responses include reduced shoot growth, fruit size and quality, and increased floral bud induction [16]. In temperate zones, soil temperature at a constant depth normally increase from spring to summer and then decrease from summer to winter, varying with soil properties and vegetation [14], and the vertical distribution of soil nutrients is a result of factors like weathering, atomospheric deposition, and leaching, where plant nutrients cycling is important. An example of this is the high content of potassium and phosphorus in the top soil layer $(20 \mathrm{~cm})$ [17]. These factors combined with abiotic interactions create high amounts of heterogeneity in the soil that make it difficult to quantify rootstock related responses to field soil environments.

Soil water limitations can impact the nutritional status of plants by affecting the absorption and allocation of nutrients among plant organs. Low water content in the soil reduces the rate of diffusion of nutrients from the soil matrix to the absorbing root surface area $[18,19]$. For macronutrients such as calcium, nitrogen, potassium, and magnesium, its absorption by the plant occurs mainly through mass flow from the soil solution into the xylem via the transpirational flow. Once inside the plant vascular system, nitogen, potassium, and magnesium can be redistributed through the phloem. Calcium, on the other hand, has low phloem mobility, and for this its capacity for redistribution once it reaches a sink organ (active growing tissue i.e., apical meristems, growing fruits and leaves, root tips) is very limited [20]. Consequentially, greater rates of water transpiration will result in a greater allocation of mineral nutrients from the root to aboveground tissues. In periods of decreased water availability, transpiration rates and root development are lower affecting the translocation of plant nutrients to aboveground tissues. These factors contribute to the association between nutrient accumulation and plant water status [19].

Nutrient ratios have been suggested to be a better indicator of the tree nutritional balance than absolute concentrations [21]. Some fruit disorders observed in apple that reduce fruit quality and marketability, such as bitter pit, are associated with nutrient imbalances or deficiencies. Bitter pit is a physiological disorder related to calcium content and the ratios of nitrogen, potassium and magnesium to calcium in the fruit [22]. Furthermore, rootstocks have been reported to affect bitter pit incidence, which can be aggravated by excessive tree vigor and fruit size, low soil $\mathrm{pH}$, boron deficiency, and environmental stresses such as drought [23]. These nutrient-related disorders may be overcome identifying rootstock genotypes with improved nutrient uptake and partitioning.

Considering that higher temperatures are expected for many apple-growing regions [6], understanding the effect of elevated soil temperatures and the reductions in water availability on mineral nutrient uptake and distribution by different roostock and scion cultivars will be critical to maintaining orchard productivity and high fruit quality [3]. The objective of this study was to determine whether rootstock and/or scion genotype differ in nutrient uptake and partitioning within plant organs under water limitations or supraoptimal $\left(>25^{\circ} \mathrm{C}\right)$ soil temperatures. We hypothesize that different belowground environments will impact nutrient uptake and distribution and that the magnitude of these responses will be dependent on rootstock and scion genotype. This study will 
provide critical information outlining how scion and rootstock genotypes interact in apple and respond to changes in soil conditions that may be experienced in the near future.

\section{Materials and Methods}

\subsection{Plant Material and Nutrient Composition}

The experiment was performed at Washington State University Tree Fruit Research and Extension Center in Wenatchee, WA ( $47^{\circ} 26^{\prime} 17.6^{\prime \prime}$ N, $120^{\circ} 20^{\prime} 48.3^{\prime \prime}$ W). Two scions, 'Honeycrisp' and 'Gala' were selected as scion cultivars because of their contrasting susceptibility to calcium-related disorders [23-26] and grafted onto four rootstocks with genotypic variation in vigor. Two of the rootstocks were from the Geneva series: G41 (dwarf) and G890 (semi-dwarf). Rootstock G41 is the most commonly used Geneva rootstock in Washington State, and G890 is the most vigorous of the selections. The other two rootstocks were M9-T337 (M9) (dwarf) which is the standard for the apple industry and breeding programs, and Bud-9 (B9) (dwarf) which is one of the most dwarfing commercially available rootstocks. Rootstock liners were planted in $10.9 \mathrm{~L}$ (diameter: $27 \mathrm{~cm}$, height: $23 \mathrm{~cm}$ ) pots using a sterile, high porosity growing medium to allow for adequate drainage and aeration (Pro-mix HP, Quakertown, PA, USA) and to avoid mineralization of nutrients by microorganisms. A week after establishment, scion wood was cleft grafted to each rootstock genotype.

Grafted trees were grown in a greenhouse between April and August 2017 under ambient light and humidity with temperatures maintained between 20 and $25{ }^{\circ} \mathrm{C}$. Trees were drip-irrigated daily for $30 \mathrm{~min}$ with emitters that applied $3.78 \mathrm{~L} \mathrm{~h}^{-1}$ until soil saturation was achieved and fertilized every two weeks ( $0.5 \mathrm{~L}$ per tree) with a water-soluble fertilizer containing $24 \%$ total nitrogen $(3.5 \%$ ammoniacal nitrogen and $20.5 \%$ urea nitrogen), $8 \%$ available phosphate $\left(\mathrm{P}_{2} \mathrm{O}_{5}\right), 16 \%$ soluble potassium $\left(\mathrm{K}_{2} \mathrm{O}\right), 0.02 \%$ boron, $0.07 \%$ water-soluble copper, $0.15 \%$ chelated manganese, $0.0005 \%$ molybdenum, and $0.06 \%$ water-soluble zinc and applied at elemental concentrations of $4.53 \mathrm{mM} \mathrm{N}, 0.68 \mathrm{mM} \mathrm{P}, 1.08 \mathrm{mM} \mathrm{K}$, $0.003 \mathrm{mM} \mathrm{Cu}, 0.007 \mathrm{mM} \mathrm{Fe}, 0.002 \mathrm{mM} \mathrm{Mn}, 1.38-5 \mathrm{mM} \mathrm{Mo}$, and $0.002 \mathrm{mM} \mathrm{Zn})$. Sufficient calcium and sulfur concentrations were present in the mountain-based water source [27].

After trees reached $45 \mathrm{~cm}$ of height approximately, trees were arranged in a split-plot design with three reps. The main plots consisted of a water-limited treatment (50\% field capacity), a heat stress treatment $\left(100 \%\right.$ field capacity with potting media heated to $5{ }^{\circ} \mathrm{C}$ above the unheated control) and a control with full irrigation (100\% field capacity). Subplots consisted of the eight rootstock-scion combinations mentioned above. Field capacity was determined by watering the trees to saturation and, after allowing the media to drain gravimetrically, measuring the volumetric water content twice per week using a capacitance EC-5 soil volumetric content sensor at $10 \mathrm{~cm}$ from the tree's trunk and to $15 \mathrm{~cm}$ depth in the pot (Decagon Devices, Pullman, WA, USA) connected to a handheld data logger (Decagon Devices, Pullman, WA, USA). For the water-limited treatment, once soil moisture had been depleted to $50 \%$ of field capacity, water was added to elevate soil moisture to just above $60 \%$ field capacity. Soil temperature was controlled using a Hydrofarm digital temperature controller (Hydrofarm, Petaluma, CA, USA) connected to heating cables and heating blankets set to elevate the temperature of the root-zone $5^{\circ} \mathrm{C}$ above ambient temperature. Pot temperature was recorded every $30 \mathrm{~min}$ in one pot per block of the heat and control treatments using a HOBO temperature sensor placed $10 \mathrm{~cm}$ from the tree's trunk and to $15 \mathrm{~cm}$ depth in the pot (Onset Computer Corp., Bourne, MA, USA). Stem water potential was measured every two weeks using a Scholander system Pressure Chamber Instrument (PMS Instrument Co., Albany, OR, USA) at solar noon to monitor plant water status [28].

\subsection{Destructive Sampling and Mineral Nutrient Analysis}

Sixty days after the start of treatment, the trees were divided into roots, stems, and leaves. Roots were carefully washed using tap water to remove potting media. Root, stem, and leaf samples were then dried to a stable weight in a chamber with constant airflow at $25^{\circ} \mathrm{C}$ for 30 days. Once dry, all samples were weighed. Leaf samples were ground into a fine powder using a VWR high throughput 
homogenizer (VWR, Radnor, PA, USA). For stems and roots, samples were initially ground to 20-micron size using a Wiley Mini mill (Thomas Scientific LLC., Swedesboro, NJ, USA) and then ground to sub-micron size using a VWR high throughput homogenizer (VWR, Radnor, PA, USA).

For mineral nutrient analysis, $200 \mathrm{mg}$ of roots, stems or leaves were weighed into PTFE tubes, and acid digested using $6 \mathrm{~mL}$ of $\mathrm{HNO}_{3}$. After digestion, the solution was filtered with a $0.45 \mu \mathrm{M}$ PTFE filter (Thermo Fisher Scientific, Waltham, MA, USA). Filtered digests were then diluted 100 $\times$ and analyzed using an Agilent 4200 microwave plasma-atomic emission spectrometer (MP-AES) (Agilent, Santa Clara, CA, USA) and run in combination with calcium, potassium, and magnesium ICP standards for validation [29]. Nitrogen content was determined using a PDZ Europa ANCA-GSL elemental analyzer interfaced to a PDZ Europa 20-20 isotope ratio mass spectrometer (Sercon Ltd., Cheshire, UK) at the UC Davis Stable Isotope Facility in Davis, CA, USA. From these measurements, concentration (mg/g of biomass) was calculated, and this value multiplied by the total biomass of each plant organ, allowing to estimate the plant organ nutrient content $(\mathrm{mg})$. Additionally, stoichiometric ratios of nitrogen to calcium $(\mathrm{N}: \mathrm{Ca})$, potassium to calcium $(\mathrm{K}: \mathrm{Ca})$, magnesium to calcium $(\mathrm{Mg}: \mathrm{Ca})$, and the sum of nitrogen, potassium and magnesium to calcium $((\mathrm{N}+\mathrm{K}+\mathrm{Mg}): \mathrm{Ca})$ in leaves were calculated.

Data were analyzed by performing an analysis of variance (ANOVA), and a Tukey's means separation with a confidence of $95 \%$ (SAS, ver. 9.4 PROC GLM).

\section{Results}

Soil water content in the pots of the water-limited treatment was effectively reduced by $40 \%$ approximately compare to the control treatments. The water content of the elevated soil temperature treatment was constantly slightly higher than control due to the use of heating blankets under the pots, possibly slowing water loss after the irrigation events (Figure 1). The root-zone average temperature was effectively elevated approximately $5{ }^{\circ} \mathrm{C}$ than water-limited and control treatments as intended (Figure 2). Mid-day stem water potential showed that the water-limited treatment caused significantly lower mid-day stem water potential relative to the control while the elevated soil temperature treatment did not affect stem water potential (Figure 3).

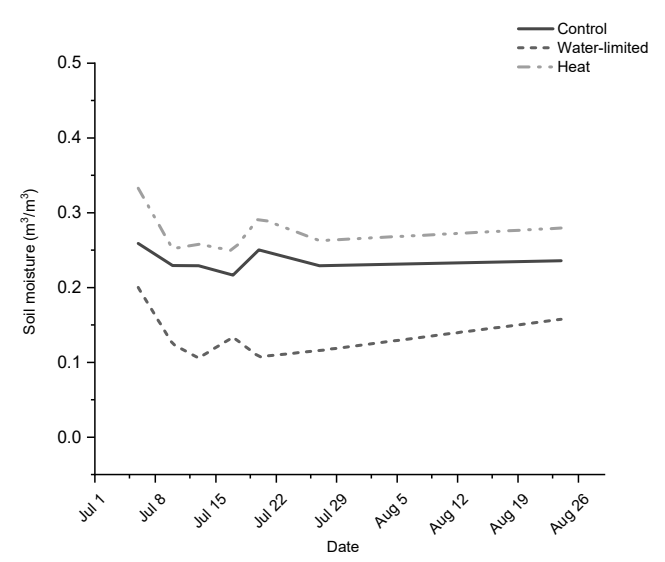

Figure 1. Mean soil volumetric water content during the growing season for control, water-limited, and elevated soil temperature treatments. 


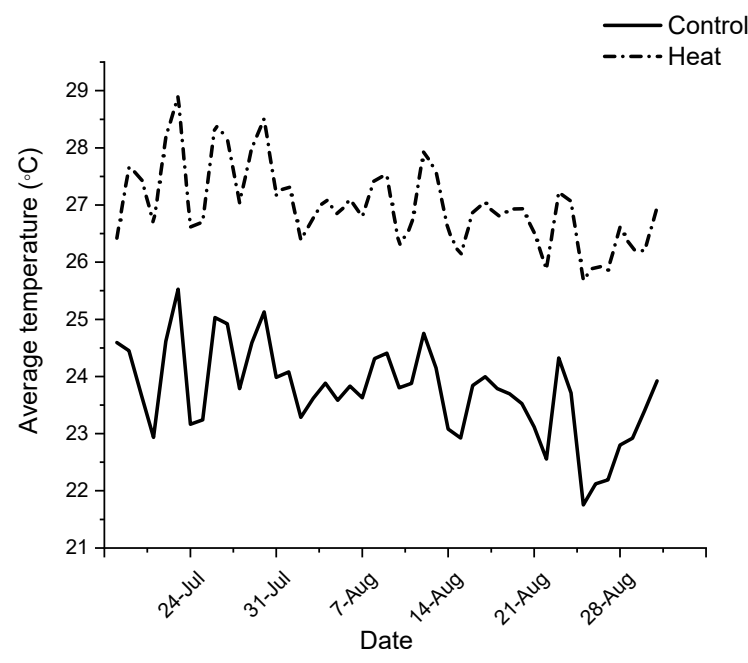

Figure 2. Daily average root-zone temperature recorded through the growing season for elevated soil temperature and control treatments.

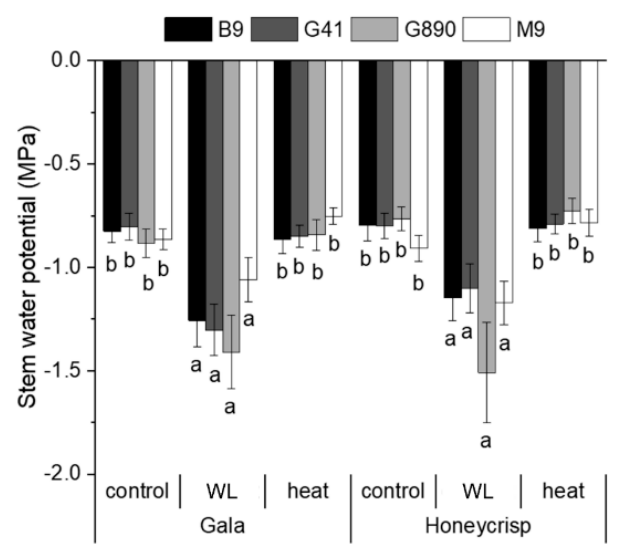

Figure 3. Mean mid-day stem water potential (MPa) for 'Gala' and 'Honeycrisp' apple cultivars grafted on B9, G41, G890, and M9 rootstocks grown under water-limited (WL) or elevated soil temperature treatments compared to an untreated control. Error bars denote standard error $(n=3)$. Letters denote significant differences among means determined using a Tukey's mean separation test $(\alpha=0.05)$.

\subsection{Plant Growth}

Leaf biomass, leaf area, stem biomass, and root:shoot ratio were affected differently for each scion and rootstock combination (Table 1). 'Gala' had 40\% more biomass than 'Honeycrisp' with G890; while there was no significant difference between scions with G41, M9, and B9. The rootstock genotypes responded differently to water limitations (Table 1). Root biomass was lower by $30 \%$ for G890 in the water-limited treatment compared to the control and elevated soil temperature, but it was not different between treatments for G41, M9, and B9. Soil treatments had significant effects on total plant growth, where the water-limited treatment reduced it on average by $40 \%$ compared to the control and elevated soil temperature treatments (Figure 4). Similarly, the water-limited treatment caused a decrease of about $34 \%$ for stem biomass, $50 \%$ for leaf biomass, and $60 \%$ for leaf area compared to the control. Interestingly, root biomass was affected by scion and was consistently higher for 'Gala' than for 'Honeycrisp.' 
Table 1. Root, stem and leaf biomass (grams dry weight), total leaf area $\left(\mathrm{cm}^{2}\right)$ and root:shoot biomass ratio $( \pm \mathrm{SE} ; n=3$ ) for 'Gala' and 'Honeycrisp' apple cultivars in combination with four rootstocks: B9, G41, G890, and M9 under water limitations or elevated soil temperatures compared to an untreated control. Values at the bottom correspond to the $p$-values of factors and its interactions that were significant for at least one variable; SE means standard error.

\begin{tabular}{|c|c|c|c|c|c|c|c|}
\hline & \multirow[b]{2}{*}{ Scion } & \multirow[b]{2}{*}{ Rootstock } & \multicolumn{5}{|c|}{ Dry Weight (G) } \\
\hline & & & $\operatorname{Root}(G)$ & Stem(G) & Leaf(G) & Leaf Area $\left(\mathrm{Cm}^{2}\right)$ & Root:Shoot \\
\hline \multirow{8}{*}{ Control } & \multirow{4}{*}{ Honeycrisp } & B9 & $4.1 \pm 0.1$ & $32.2 \pm 2.1$ & $15.8 \pm 0.7$ & $1758 \pm 114$ & $0.09 \pm 0.003$ \\
\hline & & G41 & $3.0 \pm 1.2$ & $20.8 \pm 5.5$ & $17.2 \pm 4.1$ & $2186 \pm 754$ & $0.08 \pm 0.02$ \\
\hline & & G890 & $19.5 \pm 4.7$ & $25.0 \pm 3.1$ & $19.9 \pm 3.5$ & $2610 \pm 553$ & $0.46 \pm 0.13$ \\
\hline & & M9 & $5.6 \pm 0.9$ & $33.5 \pm 3.5$ & $28.2 \pm 2.9$ & $3565 \pm 395$ & $0.09 \pm 0.01$ \\
\hline & \multirow{4}{*}{ Gala } & B9 & $7.3 \pm 0.8$ & $33.7 \pm 3.1$ & $20.0 \pm 3.9$ & $2182 \pm 331$ & $0.14 \pm 0.02$ \\
\hline & & G41 & $9.1 \pm 0.9$ & $35.0 \pm 4.9$ & $24.4 \pm 3.0$ & $350 \pm 407$ & $0.15 \pm 0.01$ \\
\hline & & G890 & $24.6 \pm 1.6$ & $40.6 \pm 2.3$ & $31.6 \pm 2.1$ & $3872 \pm 279$ & $0.34 \pm 0.02$ \\
\hline & & M9 & $8.6 \pm 0.3$ & $34.2 \pm 8.2$ & $27.2 \pm 6.3$ & $3435 \pm 706$ & $0.16 \pm 0.04$ \\
\hline \multirow{8}{*}{ Water-Limited } & \multirow{4}{*}{ Honeycrisp } & B9 & $2.3 \pm 1.0$ & $19.3 \pm 2.7$ & $5.2 \pm 2.1$ & $496 \pm 231$ & $0.09 \pm 0.02$ \\
\hline & & G41 & $5.2 \pm 1.3$ & $16.3 \pm 0.7$ & $8.7 \pm 1.3$ & $872 \pm 192$ & $0.21 \pm 0.04$ \\
\hline & & G890 & $15.9 \pm 3.1$ & $15.2 \pm 1.5$ & $7.6 \pm 1.4$ & $770 \pm 166$ & $0.76 \pm 0.25$ \\
\hline & & M9 & $6.6 \pm 0.9$ & $27.0 \pm 1.5$ & $15.9 \pm 0.6$ & $1629 \pm 131$ & $0.15 \pm 0.02$ \\
\hline & \multirow{4}{*}{ Gala } & B9 & $5.4 \pm 0.9$ & $30.4 \pm 1.7$ & $12.1 \pm 2.8$ & $1067 \pm 308$ & $0.13 \pm 0.03$ \\
\hline & & G41 & $6.0 \pm 0.2$ & $16.6 \pm 3.4$ & $9.3 \pm 1.6$ & $935 \pm 232$ & $0.24 \pm 0.03$ \\
\hline & & G890 & $17.0 \pm 4.9$ & $26.1 \pm 1.9$ & $17.8 \pm 3.1$ & $1741 \pm 261$ & $0.39 \pm 0.10$ \\
\hline & & M9 & $5.2 \pm 2.2$ & $17.6 \pm 4.1$ & $10.1 \pm 3.4$ & $1039 \pm 253$ & $0.18 \pm 0.03$ \\
\hline \multirow{8}{*}{ Heat } & \multirow{4}{*}{ Honeycrisp } & B9 & $1.8 \pm 0.4$ & $22.3 \pm 0.3$ & $10.6 \pm 2.4$ & $1237 \pm 262$ & $0.05 \pm 0.01$ \\
\hline & & G41 & $3.6 \pm 0.1$ & $24.7 \pm 5.1$ & $17.9 \pm 4.4$ & $2203 \pm 550$ & $0.08 \pm 0.004$ \\
\hline & & G890 & $24.1 \pm 5.8$ & $28.2 \pm 13.0$ & $24.1 \pm 8.4$ & $1964 \pm 1072$ & $0.51 \pm 0.09$ \\
\hline & & M9 & $5.0 \pm 1.2$ & $30.6 \pm 8.4$ & $23.2 \pm 7.0$ & $2778 \pm 944$ & $0.10 \pm 0.01$ \\
\hline & \multirow{4}{*}{ Gala } & B9 & $7.3 \pm 1.6$ & $37.2 \pm 1.4$ & $24.5 \pm 1.4$ & $2577 \pm 230$ & $0.12 \pm 0.02$ \\
\hline & & G41 & $9.7 \pm 1.1$ & $39.0 \pm 1.6$ & $32.7 \pm 2.2$ & $2841 \pm 772$ & $0.13 \pm 0.01$ \\
\hline & & G890 & $28.8 \pm 4.2$ & $48.3 \pm 14.2$ & $32.6 \pm 9.4$ & $3138 \pm 943$ & $0.43 \pm 0.12$ \\
\hline & & M9 & $3.5 \pm 0.8$ & $20.7 \pm 2.6$ & $14.9 \pm 2.5$ & $1811 \pm 203$ & $0.10 \pm 0.01$ \\
\hline \multirow{2}{*}{\multicolumn{3}{|c|}{$\begin{array}{l}\text { Treatment } \\
\text { Scion }\end{array}$}} & 0.2315 & 0.0112 & $<0.0001$ & 0.0008 & 0.1469 \\
\hline & & & 0.0030 & 0.0028 & 0.0049 & 0.0347 & $<0.0001$ \\
\hline \multicolumn{3}{|c|}{ Rootstock } & $<0.0001$ & 0.3824 & 0.0302 & 0.0377 & 0.6434 \\
\hline \multirow{2}{*}{\multicolumn{3}{|c|}{$\begin{array}{l}\text { Treatment } \times \text { Rootstock } \\
\text { Scion } \times \text { Rootstock }\end{array}$}} & 0.0354 & 0.3853 & 0.3457 & 0.7042 & 0.4294 \\
\hline & & & 0.3621 & 0.0087 & 0.0155 & 0.0507 & 0.0112 \\
\hline
\end{tabular}

Bold format intends to highly the statistically significant values from the non-significant.

\subsection{Mineral Nutrient Concentration and Partitioning}

Scion genotype had a significant effect on nitrogen concentration in roots, stems, and leaves (Table 2). Nitrogen concentrations in roots and stems were higher in 'Gala,' but 'Honeycrisp' had higher concentrations in the leaves. Rootstock genotype did not significantly affect nitrogen concentrations in any plant organ. Regarding soil treatments, trees exposed to water-limited conditions showed higher nitrogen concentrations in root and stem but lower in leaf compared to the control. Nitrogen concentrations in leaves and roots were not significantly affected by elevated soil temperatures, unlike stems which had higher values compared to the control but lower than water-limited treatments.

Calcium was less variable than nitrogen, showing greater concentrations in the stems for 'Gala' than 'Honeycrisp' but no difference for roots or leaves. Calcium concentrations in roots were higher for G41 compared to the other three rootstock genotypes but were not different for stems and leaves among rootstocks. Like nitrogen, root calcium concentrations were greater when trees were exposed to water-limited conditions compared to the control and heat treatments. However, leaf calcium concentrations were lower for trees exposed to both water-limited and elevated soil temperature treatments (Table 2). 

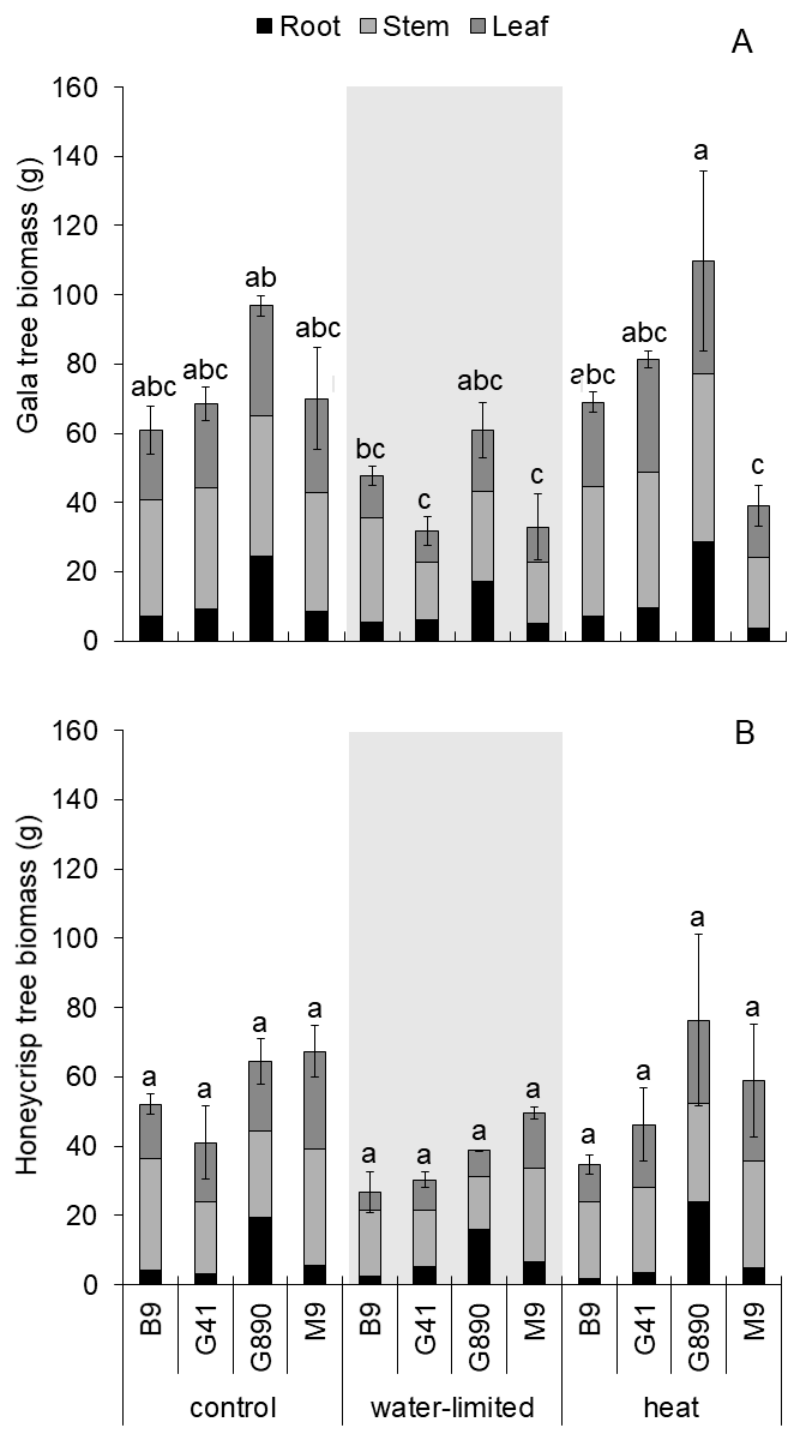

Figure 4. Mean tree biomass (grams of dry weight) distribution between roots, stems and leaves for (A) 'Gala' and (B) 'Honeycrisp' apple cultivars grafted on B9, G41, G890 and M9 rootstocks grown under water-limited or elevated soil temperature treatments compared to an untreated control. Error bars denote standard error for total tree biomass $(n=3)$. Letters denote significant differences among means determined using a Tukey's mean separation test $(\alpha=0.05)$.

Root potassium concentrations were not different between 'Gala' and 'Honeycrisp.' However, potassium concentrations were greater for 'Gala' in the stem but greater in leaves of 'Honeycrisp'. Rootstock genotype had a significant effect on root potassium concentrations but not on leaves or stems. In roots, potassium concentrations were the lowest for G890 and G41 and the highest for B9. Soil treatments only had a significant effect on leaf potassium concentrations, where like calcium, leaf potassium concentrations were lower when water was limited or when root temperatures were elevated (Table 2).

'Honeycrisp' had higher magnesium concentrations in roots but 'Gala' had higher concentrations in stem and leaves. Among rootstocks, B9 had the lowest magnesium concentrations in roots, stems, and leaves, while G41 had the highest concentration in stems and leaves, and M9 had the highest magnesium concentrations in roots. Similar to nitrogen and calcium, magnesium concentrations in trees under water limitations were greater in the roots and lower in the leaves when compared to the control. Additionally, elevated soil temperatures also resulted in lower leaf magnesium concentrations (Table 2). 
Table 2. Nitrogen, calcium, potassium, and magnesium concentration (mg/g) for roots, stems and leaves of 'Gala' and 'Honeycrisp' scion genotypes in combination with B9, G41, G890, and M9 rootstocks genotype grown in untreated control, water-limited, or elevated soil temperature treatments. Different letters denote significant differences among columns determined using a Tukey's mean separation test $(\alpha=0.05) .{ }^{* * *},{ }^{* *}$ and ${ }^{*}$ indicate significance in differences among means at $p$-values $<0.0001,<0.01$ and $<0.05$, respectively.

\begin{tabular}{|c|c|c|c|c|c|c|c|c|c|c|c|c|}
\hline & \multicolumn{2}{|c|}{ Scion } & & \multicolumn{4}{|c|}{ Rootstock } & & \multicolumn{3}{|c|}{ Treatment } & \\
\hline & ‘Gala' & 'Honeycrisp' & & B9 & G41 & G890 & M9 & & Control & Water-Limited & Heat & \\
\hline \multicolumn{13}{|l|}{ Nitrogen } \\
\hline Roots & $36.9 \mathrm{a}$ & $28.3 \mathrm{~b}$ & $* * *$ & $31.5 \mathrm{a}$ & $35.1 \mathrm{a}$ & $33.5 \mathrm{a}$ & $30.2 \mathrm{a}$ & * & $29.1 \mathrm{~b}$ & $40.6 \mathrm{a}$ & $28.0 \mathrm{~b}$ & $* * *$ \\
\hline Stems & $5.6 \mathrm{a}$ & $5.0 \mathrm{~b}$ & $* *$ & $5.3 \mathrm{a}$ & $5.2 \mathrm{a}$ & $5.0 \mathrm{a}$ & $5.5 \mathrm{a}$ & & $4.3 \mathrm{c}$ & $6.6 \mathrm{a}$ & $4.9 \mathrm{~b}$ & $* * *$ \\
\hline Leaves & $22.8 \mathrm{~b}$ & $25.7 \mathrm{a}$ & $* *$ & $23.0 \mathrm{a}$ & $24.6 \mathrm{a}$ & $24.5 \mathrm{a}$ & $24.9 \mathrm{a}$ & & $25.1 \mathrm{a}$ & $22.8 \mathrm{~b}$ & $24.9 \mathrm{a}$ & $*$ \\
\hline \multicolumn{13}{|l|}{ Calcium } \\
\hline Roots & $15.9 \mathrm{a}$ & $15.5 \mathrm{a}$ & & $14.7 \mathrm{~b}$ & $19.0 \mathrm{a}$ & $14.7 \mathrm{~b}$ & $14.5 \mathrm{~b}$ & $* *$ & $14.9 \mathrm{~b}$ & $17.6 \mathrm{a}$ & $14.7 \mathrm{~b}$ & $* *$ \\
\hline Stems & $12.0 \mathrm{a}$ & $9.2 \mathrm{~b}$ & $* * *$ & $11.3 \mathrm{a}$ & $9.9 \mathrm{a}$ & $10.7 \mathrm{a}$ & $10.4 \mathrm{a}$ & & $10.6 \mathrm{a}$ & $11.0 \mathrm{a}$ & $10.2 \mathrm{a}$ & \\
\hline Leaves & $20.8 \mathrm{a}$ & $19.5 \mathrm{a}$ & & $20.6 \mathrm{a}$ & $19.2 \mathrm{a}$ & $21.1 \mathrm{a}$ & $19.8 \mathrm{a}$ & & $22.6 \mathrm{a}$ & $19.6 \mathrm{~b}$ & $18.4 \mathrm{~b}$ & $* * *$ \\
\hline \multicolumn{13}{|l|}{ Potassium } \\
\hline Roots & $11.3 \mathrm{a}$ & $12.6 \mathrm{a}$ & & $15.6 \mathrm{a}$ & $10.6 \mathrm{bc}$ & $8.9 c$ & $12.8 \mathrm{ab}$ & $* * *$ & $12.0 \mathrm{a}$ & $12.3 \mathrm{a}$ & $11.6 \mathrm{a}$ & \\
\hline Stems & $8.3 \mathrm{a}$ & $7.5 \mathrm{~b}$ & * & $8.1 \mathrm{a}$ & $7.8 \mathrm{a}$ & $8.0 \mathrm{a}$ & $7.8 \mathrm{a}$ & & $8.2 \mathrm{a}$ & $7.4 \mathrm{a}$ & $8.1 \mathrm{a}$ & \\
\hline Leaves & $29.0 \mathrm{~b}$ & $31.1 \mathrm{a}$ & $*$ & $28.7 \mathrm{a}$ & $31.0 \mathrm{a}$ & 39.9 a & $30.6 \mathrm{a}$ & & $33.1 \mathrm{a}$ & $27.2 \mathrm{~b}$ & $29.8 \mathrm{~b}$ & $* * *$ \\
\hline \multicolumn{13}{|c|}{ Magnesium } \\
\hline Roots & $2.8 \mathrm{~b}$ & $3.1 \mathrm{a}$ & $*$ & $2.6 \mathrm{~b}$ & $3.0 \mathrm{ab}$ & $2.9 \mathrm{ab}$ & $3.4 \mathrm{a}$ & $* *$ & $2.7 \mathrm{~b}$ & $3.3 \mathrm{a}$ & $2.9 \mathrm{~b}$ & $* *$ \\
\hline Stems & $1.3 \mathrm{a}$ & $0.9 \mathrm{~b}$ & $* * *$ & $0.9 \mathrm{~b}$ & $1.3 \mathrm{a}$ & $1.2 \mathrm{ab}$ & $1.1 \mathrm{ab}$ & * & $1.2 \mathrm{a}$ & $1.0 \mathrm{a}$ & $1.1 \mathrm{a}$ & \\
\hline Leaves & $4.2 \mathrm{a}$ & $3.8 \mathrm{~b}$ & $* *$ & $3.4 \mathrm{~b}$ & $4.4 \mathrm{a}$ & $4.0 \mathrm{a}$ & $4.1 \mathrm{a}$ & $* * *$ & $4.4 \mathrm{a}$ & $3.6 \mathrm{~b}$ & $3.9 \mathrm{~b}$ & $* * *$ \\
\hline
\end{tabular}


Table 3. Nitrogen, calcium, potassium, and magnesium content (mg) for roots, stems and leaves of 'Gala' and 'Honeycrisp' scion genotypes in combination with B9, G41, G890, and M9 rootstocks genotype grown in untreated control, water-limited, or elevated soil temperature treatments. Different letters denote significant differences among columns determined using a Tukey's mean separation test $(\alpha=0.05) .{ }^{* * *},{ }^{* *}$ and ${ }^{*}$ indicate significance in differences among means at $p$-values $<0.0001$, $<0.01$ and $<0.05$, respectively.

\begin{tabular}{|c|c|c|c|c|c|c|c|c|c|c|c|c|}
\hline & \multicolumn{2}{|c|}{ Scion } & & \multicolumn{4}{|c|}{ Rootstock } & & \multicolumn{3}{|c|}{ Treatment } & \\
\hline & 'Gala' & 'Honeycrisp' & & B9 & G41 & G890 & M9 & & Control & Water-Limited & Heat & \\
\hline \multicolumn{13}{|l|}{ Nitrogen } \\
\hline Roots & $393 a$ & $235 \mathrm{~b}$ & $* * *$ & $156 \mathrm{~b}$ & $219 \mathrm{~b}$ & $701 \mathrm{a}$ & $180 \mathrm{~b}$ & $* * *$ & $309 a$ & $344 \mathrm{a}$ & $290 a$ & \\
\hline Stems & $168 \mathrm{a}$ & $120 \mathrm{~b}$ & $* * *$ & $155 \mathrm{a}$ & $128 \mathrm{a}$ & $149 \mathrm{a}$ & $143 \mathrm{a}$ & & $137 \mathrm{a}$ & $140 \mathrm{a}$ & $155 \mathrm{a}$ & \\
\hline Leaves & $492 \mathrm{a}$ & $427 \mathrm{a}$ & & $339 b$ & $464 \mathrm{ab}$ & $525 \mathrm{a}$ & 511 a & * & $573 a$ & $253 b$ & $553 \mathrm{a}$ & $* * *$ \\
\hline \multicolumn{13}{|l|}{ Calcium } \\
\hline Roots & $173 \mathrm{a}$ & $119 b$ & $* *$ & $67 \mathrm{~b}$ & $117 \mathrm{~b}$ & $316 \mathrm{a}$ & $84 \mathrm{~b}$ & $* * *$ & $147 \mathrm{a}$ & $132 \mathrm{a}$ & $159 \mathrm{a}$ & \\
\hline Stems & $382 a$ & $221 \mathrm{~b}$ & $* * *$ & $335 a$ & $255 \mathrm{~b}$ & $338 a$ & $276 \mathrm{ab}$ & * & $343 a$ & $235 \mathrm{~b}$ & $326 a$ & $* *$ \\
\hline Leaves & $445 \mathrm{a}$ & $318 \mathrm{~b}$ & $* *$ & $316 \mathrm{~b}$ & $343 a b$ & $461 \mathrm{a}$ & $407 \mathrm{ab}$ & * & $521 \mathrm{a}$ & $210 c$ & $414 \mathrm{~b}$ & $* * *$ \\
\hline \multicolumn{13}{|l|}{ Potassium } \\
\hline Roots & $111 \mathrm{a}$ & $82 \mathrm{~b}$ & $* *$ & $72 \mathrm{~b}$ & $62 \mathrm{~b}$ & $183 a$ & $69 \mathrm{~b}$ & $* * *$ & $104 \mathrm{a}$ & $91 \mathrm{a}$ & $95 \mathrm{a}$ & \\
\hline Stems & $273 a$ & $187 \mathrm{~b}$ & $* *$ & $240 \mathrm{a}$ & $206 a$ & $260 \mathrm{a}$ & $215 a$ & & $267 \mathrm{a}$ & $159 \mathrm{~b}$ & $265 a$ & $* *$ \\
\hline Leaves & $622 \mathrm{a}$ & $519 a$ & $*$ & $425 \mathrm{~b}$ & $576 \mathrm{ab}$ & $649 a$ & $632 a$ & * & $756 a$ & $290 \mathrm{~b}$ & $666 a$ & $* * *$ \\
\hline \multicolumn{13}{|c|}{ Magnesium } \\
\hline Roots & $30.2 \mathrm{a}$ & $25.3 \mathrm{a}$ & & $12.2 \mathrm{~b}$ & $17.9 \mathrm{~b}$ & $61.8 \mathrm{a}$ & $19.1 \mathrm{~b}$ & $* * *$ & $26.1 \mathrm{a}$ & $26.8 \mathrm{a}$ & $30.3 \mathrm{a}$ & \\
\hline Stems & $43.5 \mathrm{a}$ & $23.0 \mathrm{~b}$ & $* * *$ & $28.3 \mathrm{a}$ & $35.0 \mathrm{a}$ & $40.6 \mathrm{a}$ & $29.1 \mathrm{a}$ & & $39.4 \mathrm{a}$ & $21.1 \mathrm{~b}$ & $39.3 \mathrm{a}$ & $* *$ \\
\hline Leaves & $91.1 \mathrm{a}$ & $63.0 \mathrm{~b}$ & $* *$ & $52.7 \mathrm{~b}$ & $81.8 \mathrm{ab}$ & $87.6 \mathrm{a}$ & $86.1 \mathrm{a}$ & $* *$ & $104.2 \mathrm{a}$ & $39.2 \mathrm{~b}$ & $87.8 \mathrm{a}$ & $* * *$ \\
\hline
\end{tabular}


For nutrient content, 'Gala' accumulated more nitrogen, calcium, potassium, and magnesium in all plant organs, except for magnesium in roots and potassium and nitrogen in leaves. Rootstock G890 accumulated more nitrogen, calcium, potassium, and magnesium in the roots compared to the other three rootstocks (Table 3). For leaves, the differences in nutrient content were smaller than those for roots. However, largely driven by differences in biomass accumulation, nitrogen, calcium, and magnesium in roots and leaves were lower for B9 compared to the other three rootstocks. With the exception of calcium, rootstock genotype did not affect the accumulation of nutrients into stem tissue (Table 3). Interestingly, soil treatments did not affect overall nutrient content for roots but had a significant effect on aboveground nutrient content. Water limitations strongly reduced nutrient accumulation in both leaves and stems. The only exception was for nitrogen content in stems where soil treatment had no significant effect. Nitrogen, potassium, calcium, and magnesium contents of leaves under water-limited treatment were less than half of the contents of the control treatment. Elevated soil temperatures did not affect nitrogen accumulation in the leaves. However, calcium, potassium, and magnesium content were all lower compared to the control (Table 3).

Nutrient partitioning between plant organs reveals how trees distribute their nutrients under different environment scenarios (Figure 5). Nitrogen partitioning between roots and leaves was affected by scion genotype. 'Gala' had $23 \%$ more nitrogen distributed to the roots whereas 'Honeycrisp' had $13 \%$ more nitrogen distributed to the leaves. As already seen in nutrient content, G890 had the greatest partitioning of nutrients to the roots compared to the rest of the rootstock genotypes. Correspondingly, G890 accumulated the lowest proportions of nitrogen, calcium, potassium, and magnesium into the stem while B9 partitioned the most (Table 4). Rootstocks responded differently to soil treatments. Root calcium and magnesium content were greater for G890 and G41 under elevated soil temperatures and water-limited treatment compared to the control, but it was not different for the other two rootstock genotypes tested. Stem calcium content was higher for B9 under water limitations while it was no different for the other three rootstocks (Figure 5). G890 with 'Honeycrisp' had higher root potassium content than with 'Gala,' but B9 with 'Gala' had higher root nitrogen content than with 'Honeycrisp.'

\subsection{Leaf Nutrient Ratios}

Trees under elevated soil temperature showed an imbalance of mineral nutrients in their leaf tissue. A significant interaction between rootstocks and treatments was obtained, where the K:Ca, N:Ca and $\mathrm{Mg}$ :Ca ratios were greater for the rootstock G41 under elevated soil temperatures than the control and water-limited treatments while differences were not significant for G890, M9, and B9 rootstock genotypes (Figure 6). Furthermore, the K:Ca ratio was greater for 'Honeycrisp' scion than for 'Gala' among all rootstocks, with ratios of $1.62 \pm 0.04$ and $1.42 \pm 0.04$, respectively.

When nitrogen, potassium, and magnesium were combined and expressed as a ratio against calcium, rootstock genotype, scion, and soil treatment all had a significant effect. Yet again, there was a significant interaction between rootstocks and treatments where the rootstock G41 had a higher ratio for elevated soil temperature than for water-limited and control treatments while there was no difference between treatments for G890, M9, and B9 (Figure 6). Additionally, the ( $\mathrm{N}+\mathrm{K}+\mathrm{Mg}$ ):Ca ratio was greater for 'Honeycrisp' than for 'Gala' with ratios of $3.2 \pm 0.08$ and $2.7 \pm 0.08$, respectively. 

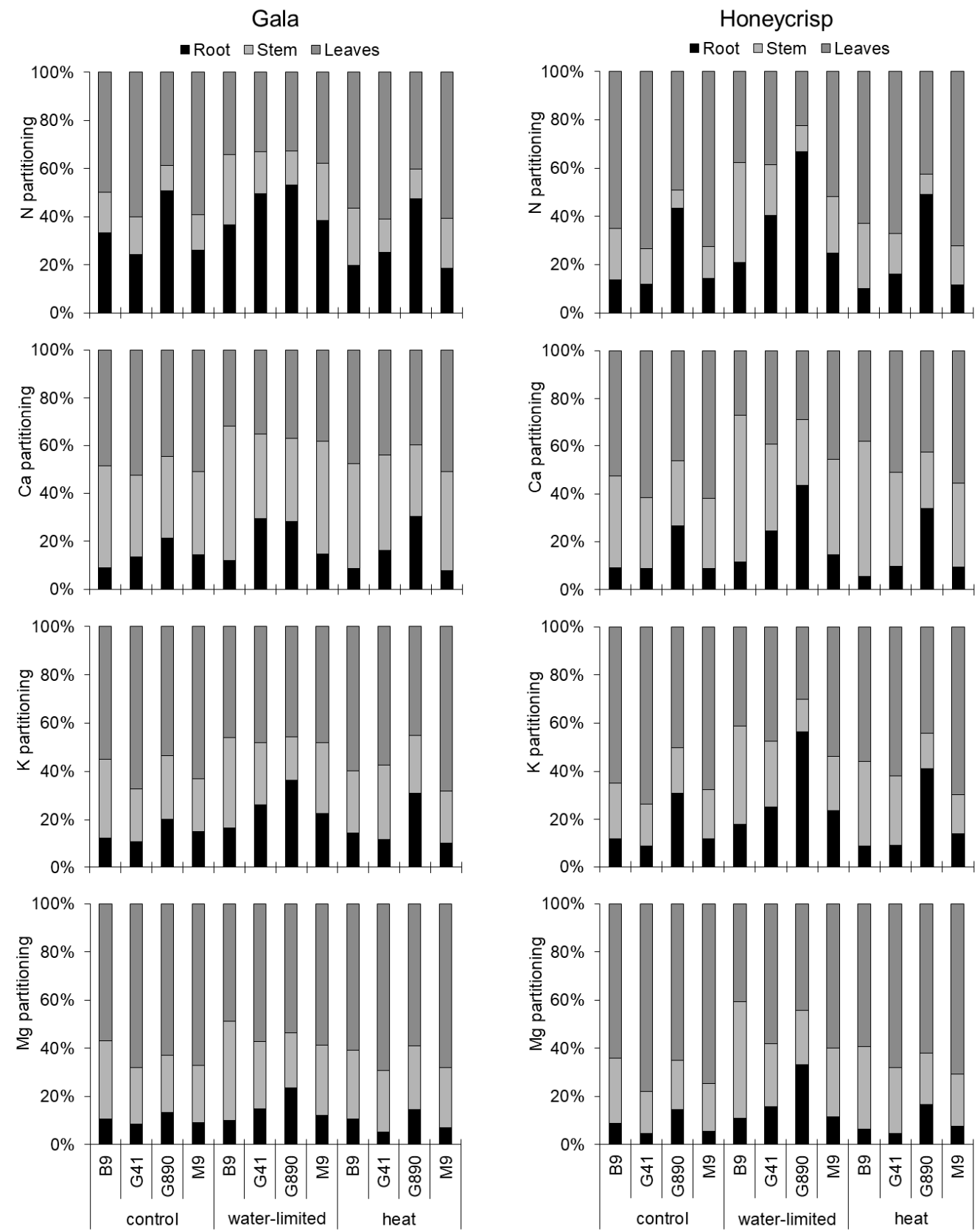

Figure 5. Total tree nitrogen, calcium, potassium and magnesium partitioning (\%) between roots, stems and leaves for 'Gala' and 'Honeycrisp' apple scion genotypes grafted on B9, G41, G890, and M9 rootstocks grown under water-limited or elevated soil temperature treatments compared to an untreated control. 
Table 4. Nitrogen, calcium, potassium and magnesium partitioning among roots, stems and leaves of 'Gala' and 'Honeycrisp' apple scion genotypes in combination with B9, G41, G890, and M9 rootstocks genotype under untreated control, water-limited, or elevated soil temperature treatments. Different letters denote significant differences among columns determined using a Tukey's mean separation test $(\alpha=0.05) .{ }^{* * *},{ }^{* *}$ and ${ }^{*}$ indicate significance in differences among means at $p$-values $<0.0001$, $<0.01$ and $<0.05$, respectively.

\begin{tabular}{|c|c|c|c|c|c|c|c|c|c|c|c|c|}
\hline \multirow{2}{*}{ Alloc/Nut (mg) } & \multicolumn{2}{|c|}{ Scion } & & \multicolumn{4}{|c|}{ Rootstock } & & \multicolumn{3}{|c|}{ Treatment } & \\
\hline & 'Gala' & 'Honeycrisp' & & B9 & G41 & G890 & M9 & & Control & Water-Limited & d Heat & \\
\hline \multicolumn{13}{|l|}{ Roots } \\
\hline Nitrogen & $0.35 \mathrm{a}$ & $0.27 \mathrm{~b}$ & $* * *$ & $0.22 \mathrm{~b}$ & $0.28 \mathrm{~b}$ & $0.52 \mathrm{a}$ & $0.22 \mathrm{~b}$ & $* * *$ & $0.27 \mathrm{~b}$ & $0.41 \mathrm{a}$ & $0.25 \mathrm{~b}$ & $* *$ \\
\hline Calcium & $0.17 \mathrm{a}$ & $0.17 \mathrm{a}$ & & $0.09 \mathrm{c}$ & $0.17 \mathrm{~b}$ & $0.31 \mathrm{a}$ & $0.12 \mathrm{c}$ & $* * *$ & $0.14 \mathrm{a}$ & $0.22 \mathrm{a}$ & $0.15 \mathrm{a}$ & \\
\hline Potassium & $0.19 \mathrm{a}$ & $0.21 \mathrm{a}$ & & $0.13 b$ & $0.15 \mathrm{~b}$ & $0.36 \mathrm{a}$ & $0.16 \mathrm{~b}$ & $* * *$ & $0.15 \mathrm{~b}$ & $0.28 \mathrm{a}$ & $0.17 \mathrm{~b}$ & $* *$ \\
\hline Magnesium & $0.12 \mathrm{a}$ & $0.11 \mathrm{a}$ & & $0.09 \mathrm{~b}$ & $0.09 \mathrm{~b}$ & $0.19 \mathrm{a}$ & $0.08 \mathrm{~b}$ & $* * *$ & $0.09 \mathrm{~b}$ & $0.16 \mathrm{a}$ & $0.09 \mathrm{~b}$ & $* *$ \\
\hline \multicolumn{13}{|l|}{ Stems } \\
\hline Nitrogen & $0.18 \mathrm{a}$ & $0.18 \mathrm{a}$ & & $0.27 \mathrm{a}$ & $0.16 \mathrm{~b}$ & $0.11 \mathrm{c}$ & $0.19 \mathrm{~b}$ & $* * *$ & $0.14 \mathrm{~b}$ & $0.23 \mathrm{a}$ & $0.17 \mathrm{~b}$ & $* * *$ \\
\hline Calcium & $0.39 \mathrm{a}$ & $0.37 \mathrm{a}$ & & $0.50 \mathrm{a}$ & $0.36 \mathrm{bc}$ & $0.29 c$ & $0.38 \mathrm{~b}$ & $* * *$ & $0.34 \mathrm{~b}$ & $0.42 \mathrm{a}$ & $0.35 \mathrm{ab}$ & $* *$ \\
\hline Potassium & $0.26 \mathrm{a}$ & $0.23 \mathrm{a}$ & & $0.33 \mathrm{a}$ & $0.25 \mathrm{~b}$ & $0.19 b$ & $0.22 b$ & $* * *$ & $0.23 \mathrm{a}$ & $0.27 \mathrm{a}$ & $0.25 \mathrm{a}$ & \\
\hline Magnesium & $0.27 \mathrm{a}$ & $0.26 \mathrm{a}$ & & $0.35 \mathrm{a}$ & $0.25 \mathrm{~b}$ & $0.23 \mathrm{~b}$ & $0.25 \mathrm{~b}$ & $* * *$ & $0.23 \mathrm{~b}$ & $0.31 \mathrm{a}$ & $0.26 \mathrm{ab}$ & $* *$ \\
\hline \multicolumn{13}{|l|}{ Leaves } \\
\hline Nitrogen & $0.47 \mathrm{~b}$ & $0.54 \mathrm{a}$ & $* * *$ & $0.51 \mathrm{~b}$ & $0.55 \mathrm{ab}$ & $0.37 \mathrm{c}$ & $0.59 \mathrm{a}$ & $* * *$ & $0.58 \mathrm{a}$ & $0.36 \mathrm{~b}$ & $0.58 \mathrm{a}$ & $* * *$ \\
\hline Calcium & $0.43 \mathrm{a}$ & $0.46 \mathrm{a}$ & & $0.41 \mathrm{~b}$ & $0.47 \mathrm{a}$ & $0.40 \mathrm{~b}$ & $0.51 \mathrm{a}$ & $* * *$ & $0.52 \mathrm{a}$ & $035 \mathrm{c}$ & $0.46 \mathrm{~b}$ & $* * *$ \\
\hline Potassium & $0.55 \mathrm{a}$ & $0.55 \mathrm{a}$ & & $0.54 \mathrm{~b}$ & $0.59 \mathrm{ab}$ & $0.45 c$ & $0.62 \mathrm{a}$ & $* * *$ & $0.62 \mathrm{a}$ & $0.45 \mathrm{~b}$ & $0.58 \mathrm{a}$ & $* * *$ \\
\hline Magnesium & $0.61 \mathrm{a}$ & $0.62 \mathrm{a}$ & & $0.55 \mathrm{~b}$ & $0.66 \mathrm{a}$ & $0.58 \mathrm{~b}$ & $0.66 \mathrm{a}$ & $* * *$ & $0.67 \mathrm{a}$ & $0.53 \mathrm{~b}$ & $0.64 \mathrm{a}$ & $* * *$ \\
\hline
\end{tabular}



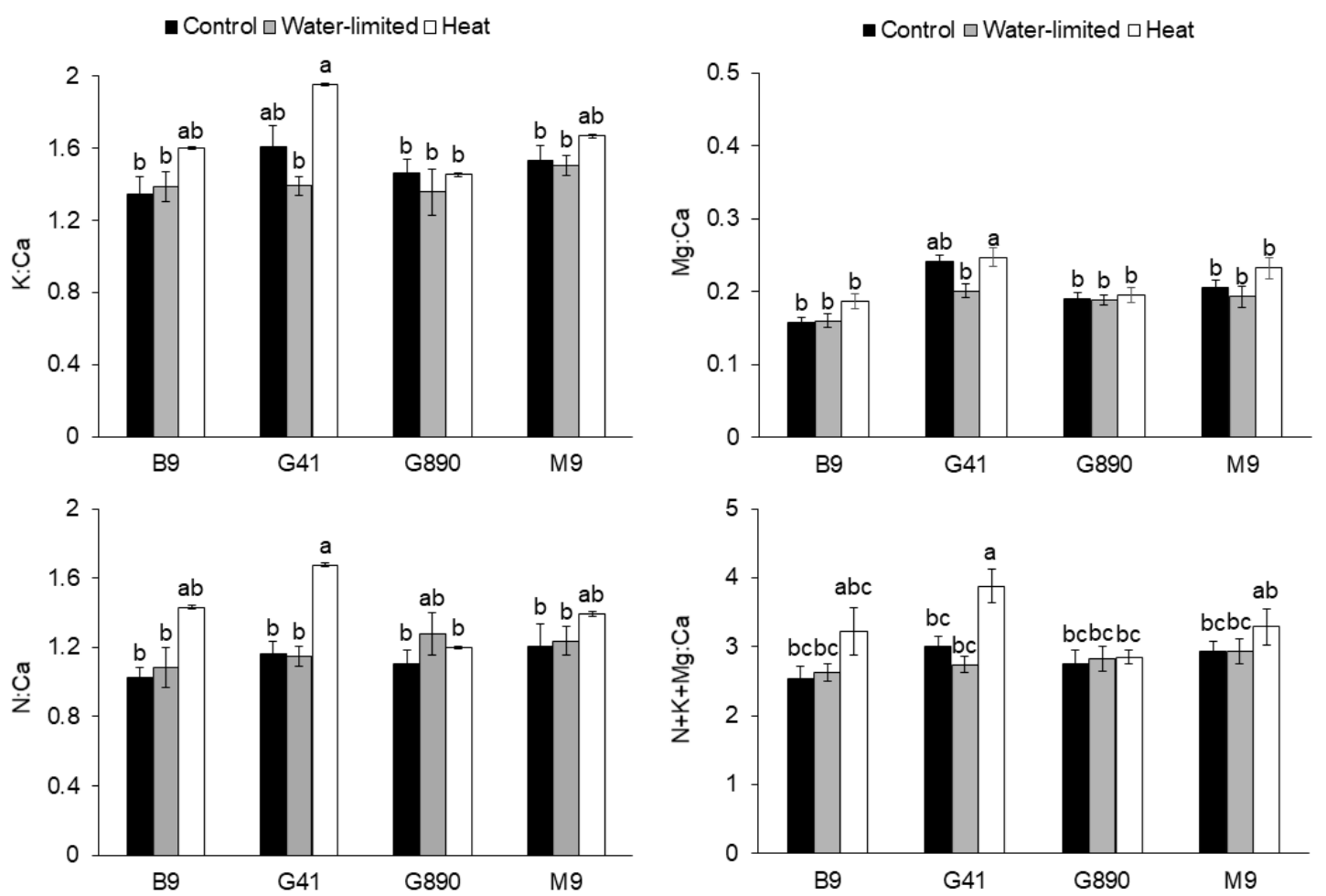

Figure 6. Mineral nutrient ratios (K:Ca, $\mathrm{N}: \mathrm{Ca}, \mathrm{Mg}: \mathrm{Ca}$ and $\mathrm{N}+\mathrm{K}+\mathrm{Mg}: \mathrm{Ca}$ ) for leaves of apple rootstocks B9, G41, G890, and M9 grown under water-limited or elevated soil temperature treatments compared to an untreated control. Error bars denote standard error $(n=3)$. Letters denote significant differences among means determined using a Tukey's mean separation test $(\alpha=0.05)$.

\section{Discussion}

\subsection{Scion and Rootstock Genotypes, and Soil Environment All Shape Plant Growth and Biomass Partitioning}

Biomass accumulation was lower under water-limited conditions and this effect was mostly driven by decreases in aboveground growth rather than belowground growth (Table 1, Figure 4). The results reported here agree with previous studies where water supply was reduced for fruit trees that led to reduced leaf area, and hence leaf biomass, while root growth was less affected which increased the root:shoot ratio [30,31]. The effect of dwarfing rootstocks on the scion under water limitations was previously reported with an elevated production of ABA in leaves which could reduce biomass partitioning to the aboveground tissues and increase root tolerance to abiotic stresses by increasing the fine root:coarse root ratio [12,31,32]. In this study, root biomass was affected by scion and was consistently higher for 'Gala' than for 'Honeycrisp'. In addition 'Gala' accumulated more above- and belowground biomass compared to 'Honeycrisp' when in combination with the G890. Since 'Gala' is a more vigorous scion than 'Honeycrisp', it is possible that it also supplied more carbohydrates to the rootstock. These results correspond with the previous reporting that scion and rootstock can both affect tree vigor. Effects on plant growth and partitioning by scion and rootstock have been reported for trunk cross-sectional area (TCA), shoot growth, tree height and the number of branches among others, i.e., the rootstock affected the scion height, TCA and weight, while the scion affected the rootstock TCA and, to a lesser extent, the root biomass [32-35]. Scion-rootstock interactions identified in a greenhouse experiment are limited because of no fruit production but these conditions allow for the evaluation of tree growth and development under a controlled environment. 


\subsection{Cultivar Differences in Nutrient Uptake and Partitioning are Independent of Biomass Accumulation}

In this study, 'Gala' accumulated more nutrients than 'Honeycrisp' (Table 3). In another study using 'Granny Smith', 'Mondial Gala', 'Lutz Golden', and 'Skyline Supreme' cultivars, leaf nutrient concentrations among cultivars differed during the growing season, where 'Mondial Gala' had the highest nutrient concentrations compared to the other cultivars used [36]. Here, 'Gala' had a dry weight consistently higher than 'Honeycrisp', although both scions had the lowest partitioning of nitrogen towards the stems, while for calcium, potassium, and magnesium the lowest sink was the roots (Table 4, Figure 5). A similar study comparing partitioning for 'Golden Delicious', 'Coxs Orange' and 'Gloster' cultivars showed that roots were the smallest sinks for nitrogen, phosphorus, and potassium while the fruit was the smallest sink for calcium in all cultivars. Moreover, 'Golden Delicious' had lower root dry weight and specific leaf weight when the nutrient supply was augmented, while there were no differences for the other two cultivars used [30]. Genotypic variation in translocating nutrients from the soil to various nutrient sinks exists [9] and it is important to consider when developing new cultivars that are less susceptible to nutrient-related disorders and improved nutrient use efficiency.

\subsection{Rootstock Affects Mineral Nutrient Uptake and Partitioning Independently of Dwarfing Effect}

Here, no differences were found for the concentrations of potassium, calcium, nitrogen and magnesium in stems and leaves among rootstocks genotypes. However, the most vigorous rootstock genotypes (G890) had the lowest potassium concentration in root tissue (Table 2). These results are in agreement with previous reports of higher concentrations of calcium and potassium in the leaves for vigorous seedling rootstocks than when grafted on dwarf rootstocks such as M9 [37]. Conversely, another study has shown that dwarf rootstock B9 had higher concentrations of calcium, zinc, and manganese in the leaves, but lower concentrations of potassium compared to more vigorous rootstocks such as Supporter4 [38]. This inconsistency in the results suggests that the effect of dwarfing capacity itself does not affect the nutrient uptake, and other factors such as hydraulic conductivity, xylem anatomy, and the ability of the root system to uptake minerals may be critical [37]. In addition, the independence of dwarfing capacity on nutrient uptake has been previously reported [9].

Nutrient content, which integrates biomass, was more closely related to dwarfing capacity. Our results showed a higher content of nitrogen, calcium, potassium, and magnesium on the roots of the G890 rootstock with both cultivars compared to less vigorous rootstocks such as G41, M9, and B9 (Table 3). These results align with a previous study where a semi-dwarf rootstock (MM106), and a strong rootstock (MM111) had a significantly greater mineral content compared to more dwarf rootstocks (M9 and M26) and were related to the higher root dry weight [36]. A larger root system increases the soil area explored and increases the absorption capacity of mineral nutrients [10]. In this study, the partitioning of nutrients was similar for all the elements (Table 4), which indicates that the partitioning is not completely dependent on rootstock vigor and that improvements in nutrient uptake and partitioning could be made without compromising vigor control in new rootstocks.

\subsection{Elevated Soil Temperatures Affect Nutrient Uptake and Partitioning Differently}

In this study, elevated soil temperature affected nutrient balance and biomass allocation in apple trees. It was previously reported that root-zone temperatures affect shoot growth and development, including budbreak, bloom, shoot extension growth, photosynthesis, and stomatal conductance [39]. Moreover, surface soil temperature was found to be the biggest environmental factor, together with surface soil water content affecting soil respiration, which can be an indicator of root growth and root metabolism [40]. Root temperatures also appear to influence carbon balance between below- and aboveground tissues [15]. Here, the aboveground biomass for both Geneva rootstocks G890 and G41 was higher when under elevated soil temperatures but was lower for B9 and M9 compared to control (Figure 4). Additionally, elevated soil temperature conditions increased the N:Ca and K:Ca ratios in leaves of G41 (Figure 6). Elevated soil temperatures have been reported to reduce potassium, sodium, 
calcium, magnesium, and zinc content when soil temperatures were above $25^{\circ} \mathrm{C}$ [41]. Calcium is mainly absorbed by root tips and also by the sites of formation of new branches [24,42]. Since elevated root temperatures can reduce root growth, calcium absorption capacity may also be lower as a result.

\subsection{Water Limitations Can Affect Nutrient Uptake and Allocation to Aboveground Organs}

Nutrient concentrations under water limitations were higher in structural organs like roots and stems when compared to active growing tissue such as leaves. Under water limitations, the concentration of nitrogen, calcium, and magnesium was lower in root tissues, while in stem tissue only nitrogen concentration was lower and the concentration of all nutrients was lower in leaves tissues compared to control (Table 2). Similar results were reported on non-irrigated 'Cox' and 'Queen Cox' apple trees leaves that had a lower concentration of nitrogen, magnesium, and manganese than irrigated trees $[38,43,44]$. Under low soil water content, the rate of diffusion of nutrients from the soil matrix to the absorbing root surface is lowered [16,17]. Most of the elemental budget of a plant comes from the root system through mass flow carried by the water in the soil medium, driven by a gradient of osmotic potential between the soil solution and the xylem sap [45]. Additionally, slow root growth under water limitations may also reduce the soil volume occupied by roots, and the nutrient transport from the roots to the shoots may also decrease due to a reduction in transpiration rates [16,46-48], e.g., in fruiting trees, the overall distribution of calcium between vegetative growth and developing fruit can be affected by changes in transpiration [49-52]. Since leaf water potential was lower under water limitations (Figure 3), stomatal closure results that can reduce the transpiration flow of nutrients via xylem to the aboveground tissues.

\subsection{Broad Implications on Nutrient Balance and Fruit Disorders under Changing Soil Environments}

Even though leaf ratios are difficult to compare to fruit ratios, which have been more extensively described [21], physiological disorders such as bitter pit are linked more strongly to the $\mathrm{K}: \mathrm{Ca}, \mathrm{N}: \mathrm{Ca}$, $\mathrm{Mg}: \mathrm{Ca}$, and $(\mathrm{N}+\mathrm{K}+\mathrm{Mg}): \mathrm{Ca}$ ratios than to calcium content itself [22]. Our study report higher $\mathrm{K}: \mathrm{Ca}, \mathrm{N}: \mathrm{Ca}$ and $(\mathrm{N}+\mathrm{K}+\mathrm{Mg})$ :Ca ratios for 'Honeycrisp' apple than 'Gala,' which is in concordance with the already known 'Honeycrisp' susceptibility to bitter pit [23]. Moreover, rootstocks G41 and M9 had higher leaf K:Ca and Mg:Ca ratios than B9 and G890 rootstocks showing the differences in nutrient uptake capacity among rootstocks previously reported $[9,24,25,37]$. Furthermore, elevated soil temperature conditions increased the N:Ca and K:Ca ratios in the leaves of G41 (Figure 6), due to lower calcium concentration (Table 2). This may be a function of calcium immobility in the phloem that limits its redistribution between plant organs [36] since the concentration of calcium was not reduced in root and stem tissues. It was previously reported that optimal soil temperatures for M9, leading to increased potassium accumulation occurs at $25^{\circ} \mathrm{C}$ [41], and similar to the findings reported here, elevated soil temperatures increased potassium uptake from the soil which contributes to an imbalance in the nutrient ratios in the leaves.

\section{Conclusions}

Water limitations affected biomass partitioning of young apple trees, reducing stem and leaf biomass and, to a lesser extent, root biomass. Through strong reductions in aboveground growth, water limitations decreased mineral nutrient content in both stems and leaves, whereas elevated soil temperatures reduced calcium partitioning to leaves. Most importantly, G890, the rootstock with the most vigor, was the most responsive to water limitations, whereas more dwarfing rootstocks were affected to a lesser degree. Since this study was conducted on potted trees using growing media, field validation is still required to strengthen these results. Nevertheless, it was demonstrated that both rootstock and scion differences contribute to nutrient uptake and partitioning under different soil environments. 'Gala' apple trees produced more biomass than 'Honeycrisp' trees, and 'Gala' trees accumulated more nitrogen in roots whereas 'Honeycrisp' trees accumulated more nitrogen in leaves showing the scion effect on the nutrient's uptake and distribution. Furthermore, rootstock genotypes 
also contributed significantly although vigor contribution to the nutrient uptake capacity is still unclear. These interactions represent a critical system for understanding how scions and rootstocks interact and, more practically, also provide information on how nutrient management decisions may change under poor soil conditions or water management and depending on rootstock-cultivar selection.

Author Contributions: Conceptualization: L.C.; L.K.; N.A.V.; methodology: N.A.V.; L.K.; validation: N.A.V.; L.K.; L.C.; formal analysis: N.A.V.; L.K.; investigation: N.A.V.; L.K.; resources: L.K.; data curation: N.A.V.; L.K.; writing-original draft preparation: N.A.V.; L.K.; writing-review and editing: L.C.; L.K.; N.A.V.; supervision: L.K.

Funding: This research was funded by USDA National Institute of Food and Agriculture-Specialty Crop Research Initiative project "AppleRoot2Fruit: Accelerating the development, evaluation, and adoption of new apple rootstocks" (2016-51181-25406). L.K. was supported by the USDA National Institute of Food and Agriculture, Hatch/Multi-State project 1014919.

Acknowledgments: We would like to acknowledge the support of Chris Sater and Hector Camargo-Alvarez for assistance with manuscript revision and to Katie Mullin for technical assistance.

Conflicts of Interest: The authors declare no conflict of interest.

\section{References}

1. Lauri, P.É.; Barigah, T.S.; Lopez, G.; Martinez, S.; Losciale, P.; Zibordi, M.; Manfrini, L.; Corelli-Grappadelli, L.; Costes, E.; Regnard, J.L. Genetic variability and phenotypic plasticity of apple morphological responses to soil water restriction in relation with leaf functions and stem xylem conductivity. Trees 2016, 30, 1893-1908. [CrossRef]

2. Wood, A.J. Eco-physiological Adaptations to Limited Water Enviornments. In Plant Abiotic Stress; Matthew, A.J., Paul, M.H., Eds.; Blackwell Publishing Ltd.: Oxford, UK, 2005; pp. 1-13.

3. Kalcsits, L.; Musacchi, S.; Layne, D.R.; Schmidt, T.; Mupambi, G.; Serra, S.; Mendoza, M.; Asteggiano, L.; Jarolmasjed, S.; Sankaran, S.; et al. Above and below-ground environmental changes associated with the use of photoselective protective netting to reduce sunburn in apple. Agric. For. Meteorol. 2017, 237, 9-17. [CrossRef]

4. Liu, B.H.; Cheng, L.; Liang, D.; Zou, Y.J.; Ma, F.W. Growth, gas exchange, water-use efficiency, and carbon isotope composition of 'Gale Gala' apple trees grafted onto 9 wild Chinese rootstocks in response to drought stress. Photosynthetica 2012, 50, 401-410. [CrossRef]

5. Sofo, A.; Palese, A.M.; Casacchia, T.; Dichio, B. Sustainable fruit production in mediterranean orchards subjected to drought stress. In Abiotic Stress Responses in Plants: Metabolism, Productivity and Sustainability; Ahmad, P., Prasad, M.N.V., Eds.; Springer: New York, NY, USA, 2012; pp. 105-129.

6. Stöckle, C.O.; Nelson, R.L.; Higgins, S.; Brunner, J.; Grove, G.; Boydston, R.; Whiting, M.; Kruger, C. Assessment of climate change impact on Eastern Washington agriculture. Clim. Chang. 2010, 102, 77-102. [CrossRef]

7. Vano, J.A.; Scott, M.J.; Voisin, N.; Stöckle, C.O.; Hamlet, A.F.; Mickelson, K.E.B.; Elsner, M.M.; Lettenmaier, D.P. Climate change impacts on water management and irrigated agriculture in the Yakima River Basin, Washington, USA. Clim. Chang. 2010, 102, 287-317. [CrossRef]

8. Wertheim, S.J.; Webster, A. Apple Rootstocks. In Apples Botany, Production and Use; Ferre, D.C., Warrington, I.J., Eds.; CABI Publishing: Cambridge, MA, USA, 2003.

9. Fazio, G.; Kviklys, D.; Grusak, M.A.; Robinson, T. Phenotypic Diversity and QTL Mapping of Absorption and Translocation of Nutrients by Apple Rootstocks. Asp. Appl. Biol. 2013, 119, 37-50.

10. Atkinson, D.; Wilson, S.A. The Growth and Distribution of Fruit Tree Roots: Some Consequences for Nutrient Uptake. In Mineral Nutrition of Fruit Trees; Elsevier BV: Amsterdam, The Netherlands, 1980; pp. 137-150.

11. Jackson, J.E. Apple and pear root systems: Induction, development, structure and function. In Biology of Apples and Pears; Cambridge University Press: Cambridge, NY, USA, 2003; pp. 84-125.

12. Tworkoski, T.; Fazio, G.; Glenn, D.M. Apple rootstock resistance to drought. Sci. Hortic. 2016, $204,70-78$. [CrossRef]

13. Bassirirad, H. Kinetics of nutrient uptake by roots: Responses to global change. New Phytol Kinetics of nutrient uptake by roots: Responses to global change. New Phytol. 2000, 147, 155-169. [CrossRef]

14. King, J.S.; Burton, A.J.; Brown, S.E.; Pregitzer, K.S. Responses of tree fine roots to temperature. New Phytol. 2000, 147, 105-115. 
15. Gur, A.; Mizrahi, Y.; Samish, R.M. The Influence of Root Temperature on Apple Trees II. Clonal Differences in Susceptibility to Damage Caused by Supraoptimal Root Temperature. J. Hortic. Sci. 1976, 51, $195-202$. [CrossRef]

16. Atkinson, C.; Webster, A.; Vaughan, S.; Lucas, A. Effects of root restriction on the physiology of apple tree growth. Acta Hortic. 1997, 451, 587-598. [CrossRef]

17. Jobbágy, E.G.; Jackson, R.B.; Jobbagy, E.G.; Jackson, R.B. The Distribution of Soil Nutrients with Depth: Global Patterns and the Imprint of Plants Linked references are available on JSTOR for this article: The distribution of soil nutrients with depth: Global patterns and the imprint of plants. Biogeochemistry 2001, 53, 51-77. [CrossRef]

18. Duman, F. Uptake of mineral elements during abiotic stress. In Abiotic Stress Responses in Plants: Metabolism, Productivity and Sustainability; Ahmad, P., Prasad, M.N.V., Eds.; Springer: New York, NY, USA, 2012; pp. 267-281.

19. Hu, Y.; Burucs, Z.; Von Tucher, S.; Schmidhalter, U. Short-term effects of drought and salinity on mineral nutrient distribution along growing leaves of maize seedlings. Environ. Exp. Bot. 2007, 60, 268-275. [CrossRef]

20. White, P.J. Long-distance Transport in the Xylem and Phloem. In Marschner's Mineral Nutrition of Higher Plants; Elsevier BV: Amsterdam, The Netherlands, 2012; pp. 49-70.

21. Casierra-posada, F.; Lizarazo, L.M. Estado nutricional de árboles de manzano Anna durante la estación de crecimiento en los altiplanos Colombianos: II. Relaciones e interacciones entre nutrientes. Agron. Colomb. 2004, 22, 160-169.

22. De Freitas, S.T.; do Amarante, C.V.T.; Mitcham, E.J. Mechanisms regulating apple cultivar susceptibility to bitter pit. Sci. Hortic. 2015, 186, 54-60. [CrossRef]

23. Rosenberger, D.; Schupp, J.; Hoying, S.; Cheng, L.; Watkins, C. Controlling Bitter Pit in Honeycrisp Apples. Horttechnology 2004, 14, 342-349. [CrossRef]

24. Buwalda, J.; Lenz, F. Effects of cropping, nutrition and water supply on accumulation and distribution of biomass and nutrients for apple trees on'M9'root systems. Physiol. Plant 1992, 84, 21-28. [CrossRef]

25. Atkinson, C.J.; Policarpo, M.; Webster, A.D.; Kuden, A.M. Drought tolerance of apple rootstocks: Production and partitioning of dry matter. Plant Soil 1999, 206, 223-235. [CrossRef]

26. Lordan, J.; Fazio, G.; Francescatto, P.; Robinson, T. Effects of apple (Malus $\times$ domestica) rootstocks on scion performance and hormone concentration. Sci. Hortic. 2017, 225, 96-105. [CrossRef]

27. Tworkoski, T.; Fazio, G. Effects of Size-Controlling Apple Rootstocks on Growth, Abscisic Acid, and Hydraulic Conductivity of Scion of Different Vigor. Int. J. Fruit Sci. 2015, 15, 1-13. [CrossRef]

28. Lauri, P.E.; Maguylo, K.; Trottier, C. Architecture and size relations: An essay on the apple (Malus $x$ domestica, Rosaceae) tree. Am. J. Bot. 2006, 93, 357-368. [CrossRef] [PubMed]

29. Costes, E.; García-Villanueva, E. Clarifying the Effects of Dwarfing Rootstock on Vegetative and Reproductive Growth during Tree Development: A Study on Apple Trees. Ann. Bot. 2007, 100, 347-357. [CrossRef]

30. Kucukyumuk, Z.; Erdal, I. Rootstock and cultivar effect on mineral nutrition, seasonal nutrient variation and correlations among leaf, flower and fruit nutrient concentrations in apple trees. Bulg. J. Agric. Sci. 2011, 17, 633-641.

31. Amiri, M.E.; Fallahi, E.; Safi-Songhorabad, M. Influence of rootstock on mineral uptake and scion growth of Golden delicious and Royal gala apples. J. Plant Nutr. 2014, 37, 16-29. [CrossRef]

32. Fallahi, E. Influence of Rootstock and Irrigation Methods on Water Use, Mineral Nutrition, Growth, Fruit Yield, and Quality in 'Gala' Apple. Horttechnology 2012, 22, 731-737. [CrossRef]

33. Wünsche, J.N.; Greer, D.H.; Norling, C.L.; Wiggins, H.N. Root-zone temperatures affect phenology of bud break, flower cluster development, shoot extension growth and gas exchange of Braeburn (Malus domestica) apple trees. Tree Physiol. 2006, 26, 105-111.

34. Ceccon, C.; Panzacchi, P.; Scandellari, F.; Prandi, L.; Ventura, M.; Russo, B.; Millard, P.; Tagliavini, M. Spatial and temporal effects of soil temperature and moisture and the relation to fine root density on root and soil respiration in a mature apple orchard. Plant Soil 2011, 342, 195-206. [CrossRef]

35. Gur, A.; Hepner, J.; Shulman, Y. The influence of root temperature on apple trees. IV. The effect on the mineral nutrition of the tree. J. Hortic. Sci. 1979, 54, 313-321. [CrossRef]

36. Ferguson, I.B.; Watkins, C.B. Bitter pit in apple fruit. Hortic. Rev. Am. Soc. Hortic. Sci. 1989, 11, $289-355$. 
37. Jackson, J.E. Eating quality and its retention. In The Biology of Apples and Pears; Cambridge University Press: Cambridge, NY, USA, 2003; pp. 341-383.

38. Atkinson, C.J.; Taylor, L.; Taylor, J.M.; Lucas, A.S. Temperature and irrigation effects on the cropping, development and quality of Cox's Orange Pippin and Queen Cox apples. Sci. Hortic. 1998, 75, 59-81. [CrossRef]

39. Slowik, K.; Labanauskas, C.K.K.; Stolzy, L.H.H.; Zentmyer, G.A.A. Influence of rootstocks, soil oxygen, and soil moisture on the uptake and translocation of nutrients in young avocado. J. Am. Soc. Hortic. Sci. 1979, 104, 172-175.

40. Jackson, J.E. Biology of Apples and Pears; Cambridge University Press: Cambridge, NY, USA, 2003.

41. Montanaro, G.; Dichio, B.; Xiloyannis, C. Significance of fruit transpiration on calcium nutrition in developing apricot fruit. J. Plant Nutr. Soil Sci. 2010, 173, 618-622. [CrossRef]

42. Montanaro, G.; Dichio, B.; Xiloyannis, C.; Lang, A. Fruit transpiration in kiwifruit: Environmental drivers and predictive model. AoB Plants 2012, 2012, pls036. [CrossRef] [PubMed]

43. De Freitas, S.T.; Amarante, C.V.D.; Labavitch, J.M.; Mitcham, E.J. Cellular approach to understand bitter pit development in apple fruit. Postharvest Boil. Technol. 2010, 57, 6-13. [CrossRef]

44. De Freitas, S.T.; Amarante, C.V.D.; Dandekar, A.M.; Mitcham, E.J. Shading affects flesh calcium uptake and concentration, bitter pit incidence and other fruit traits in Greensleeves apple. Sci. Hortic. 2013, 161, $266-272$. [CrossRef]

45. White, P.J.; Broadley, M.R. Calcium in plants. Ann. Bot. 2003, 92, 487-511. [CrossRef] [PubMed]

46. Montanaro, G.; Dichio, B.; Lang, A.; Mininni, A.N.; Xiloyannis, C. Fruit calcium accumulation coupled and uncoupled from its transpiration in kiwifruit. J. Plant Physiol. 2015, 181, 67-74. [CrossRef] [PubMed]

47. Kalcsits, L.; Van Der Heijden, G.; Reid, M.; Mullin, K. Calcium Absorption during Fruit Development in 'Honeycrisp' Apple Measured Using 44Ca as a Stable Isotope Tracer. Hortscience 2017, 52, 1804-1809. [CrossRef]

48. Lang, A. Xylem, Phloem and Transpiration Flows in Developing Apple Fruits. J. Exp. Bot. 1990, 41, 645-651. [CrossRef]

49. Watkins, C.B.; Nock, J.F.; A Weis, S.; Jayanty, S.; Beaudry, R.M. Storage temperature, diphenylamine, and pre-storage delay effects on soft scald, soggy breakdown and bitter pit of Honeycrisp apples. Postharvest Biol. Technol. 2004, 32, 213-221. [CrossRef]

50. Public Utility District. Water Quality 2018 Annual Report; Public Utility District: Wenatchee, WA, USA, 2018.

51. Shackel, K.; Lampinen, B.; Southwick, S.; Olson, W.; Sibbett, S.; Krueger, W.; Yeager, J.; Goldhamer, D. Deficit Irrigation in Prunes: Maintaining Productivity with Less Water. Hortscience 2000, 35, 1063-1066. [CrossRef]

52. Kalcsits, L.A. Non-destructive Measurement of Calcium and Potassium in Apple and Pear Using Handheld X-ray Fluorescence. Front. Plant Sci. 2016, 7, 6. [CrossRef] [PubMed] 